Article

\title{
Is There Progress towards Environmental Sustainability among Road Haulage Companies?
}

\author{
Markus Pöllänen ${ }^{1, * \mathbb{C}}$, Timo Liljamo ${ }^{2}$, Erika Kallionpää ${ }^{1}$ and Heikki Liimatainen ${ }^{1} \mathbb{C}$ \\ 1 Transport Research Centre Verne, Tampere University, 33014 Tampere, Finland; \\ erika.kallionpaa@tuni.fi (E.K.); heikki.liimatainen@tuni.fi (H.L.) \\ 2 Centre for Economic Development, Transport and the Environment for South Ostrobothnia, \\ 65100 Vaasa, Finland; timo.liljamo.ely@gmail.com \\ * Correspondence: markus.pollanen@tuni.fi
}

Citation: Pöllänen, M.; Liljamo, T.; Kallionpää, E.; Liimatainen, H. Is There Progress towards Environmental Sustainability among Road Haulage Companies? Sustainability 2021, 13, 5845. https:// doi.org/10.3390/su13115845

Academic Editor: Armando Cartenì

Received: 12 April 2021

Accepted: 10 May 2021

Published: 22 May 2021

Publisher's Note: MDPI stays neutral with regard to jurisdictional claims in published maps and institutional affiliations.

Copyright: (c) 2021 by the authors. Licensee MDPI, Basel, Switzerland. This article is an open access article distributed under the terms and conditions of the Creative Commons Attribution (CC BY) license (https:// creativecommons.org/licenses/by/ $4.0 /)$.

\begin{abstract}
Road freight transport contributes to a significant and growing share of greenhouse gas emissions. This study analyses the development of environmental practices and awareness of road freight hauliers and whether hauliers witness an interest from their shippers towards energy efficiency. Results of an original survey $(\mathrm{N}=256)$ conducted in 2019 among Finnish hauliers are presented and compared with those from a similar survey completed in $2011(\mathrm{~N}=295)$. The results highlight the lack of improvement in hauliers' environmental practices during a decade when ambitious climate goals were set. Even though hauliers share the view that emissions from road freight transport must be reduced in future, their environmental practices did not change much during the 2010s. The hauliers rarely perceive an interest from their shippers towards energy efficiency. The results show that hauliers should be supported and encouraged to pursue more environmentally aware practices. Shippers in the supply chain should be a driver, not an obstacle, to increasing road hauliers' sustainability. There should be more communication between hauliers and supply chain actors, and environmental sustainability should gain more importance when selecting carriers.
\end{abstract}

Keywords: road freight; road haulage; road haulage company; road haulier; road freight transport company; environment; emissions; sustainability; survey

\section{Introduction}

Environmental sustainability plays a significant role in future road freight transport. Transport is the single largest source of environmental hazards in logistics [1], and road transport is the backbone of logistics operations; therefore, the supply chain (SC) community needs to address the sustainability issues of transport, even if logistics activities and road freight especially are outsourced to a high degree. Global $\mathrm{CO}_{2}$ emissions from transport represent $18 \%$ of human-made emissions [2]. Road freight transport currently accounts for approximately one quarter of $\mathrm{CO}_{2}$ emissions from transport, but this share is expected to increase significantly as emissions from road freight transport are expected to grow, despite large improvements in energy efficiency [2-4]. The European Green Deal aims to achieve a $90 \%$ reduction in transport greenhouse gas emissions by 2050 [5].

All stakeholders experience pressure to reduce negative impacts on the environment because transport depends heavily on fossil fuels, resulting in high $\mathrm{CO}_{2}$ emissions [6]. However, it is unclear who should bear the responsibility for making freight transport more sustainable; moreover, there is little coordination between actors [7]. Nilsson et al. [8] asked this in, "Who controls transport emissions and who cares?", and highlighted the issue of monitoring environmental sustainability in the chain of customers, logistics service providers (LSPs), and hauliers. In this study, we investigate the issue from the hauliers' perspective, whereas Nilsson et al. [8] investigated customers' and LSPs' perspectives. Hauliers are the ones producing emissions with their fleet's operation; therefore, they are 
key players at the end of the day, although many companies in the transport and logistics sector seem to lack environmental measures [9].

The transport sector is dominated by small and medium-sized enterprises (SMEs) which often lack resources in terms of knowledge, time, and money to address sustainability, and which face strong pricing pressure and small margins; therefore, companies in general are unable to invest outside of their core business [9]. From this perspective, it is vital that sustainability in practice, e.g., reducing fuel consumption and improving energy efficiency, is seen as a part of road haulage companies' core business. Information is currently lacking on the actual situation and sustainability development in road freight companies. As the pressure towards increased environmental sustainability grows, it is important to be aware of the development of sustainability, environmental practices adopted, and the environmental attitudes in road freight companies to be able to adjust policies and actions to support a transition towards sustainability in the road haulage sector.

Previous studies have typically analysed the attitudes of road hauliers towards environmental issues and environmentally related practices based on surveys of company representatives or lorry drivers-see, e.g., [10-12]. Interviews have also been implemented as a means to gather information on the attitudes of drivers or company representatives [10], which included consulting and collecting views from trade organisations. Moreover, the case method has been implemented to study third-party logistics (3PL) service providers' involvement in green initiatives [13]. Mixed-methods approaches have also been implemented. For example, Oberhofer and Fürst [14] used a literature study and website analysis followed by interviews, a survey questionnaire and quantitative analysis to study Austrian road transport companies.

Oberhofer and Fürst [15] found that the implementation of environmental management in a road haulage company is a function of general, external, and internal influencing factors. General factors include firm size and sector affiliation, whereas the external factors include regulations and stakeholder interests (i.e., the requirements of society and customers), and internal factors comprise decision makers' attitudes and profitability. These different factors influence the overall and environmental performance of a company as well as its image and profit. In this study, we analyse how certain general factors (size and haulage sector) as well as external (shippers' interest) and internal factors (decision makers' attitudes) affect how road haulage companies in Finland have adopted certain environmental practices and what their environmental attitudes are. The situation in the operational environment changed during the 2010s with the climate change discussion evolving towards a debate on the climate crisis; therefore, there is an increased need to acknowledge the views of different SC stakeholders in order to meet sustainability targets, minimise environmental effects, and continue sustainable development work in logistics and supply chain management (SCM). This study aimed to compare the views of road hauliers in 2019 with previous studies to discover whether environmental sustainability issues and actions are recognised and implemented differently today, and if so, in what terms.

This study presents original results from a survey completed in November-December 2019 among Finnish road haulage companies. The survey included 256 respondents, representing mostly small hauliers. The situation in 2019 was compared to the results of a survey conducted in $2011(\mathrm{~N}=295)$ on a similar sample and with mostly the same survey questions. The results of the 2011 survey are reported by Liimatainen et al. [12]. Survey data were analysed related to practices around setting targets for reducing fuel consumption and monitoring consumption and perceived interest from shippers towards hauliers' energy efficiency. To allow comparison, research questions (RQs) 1, 2, and 3 of this study were aligned with those of Liimatainen et al. [12]. RQ3 addresses external factors (shippers' interests) and RQ4 investigates decision makers' attitudes (i.e., hauliers' attitudes towards environmental goals and measures), both mentioned by Oberhofer and Fürst [15] as factors influencing hauliers' environmental management. RQ5 also relates to the study by Oberhofer and Fürst [15], who noticed a significant influence of attitude 
towards sustainability on a company's actual environmental behaviour among Austrian hauliers, investigating whether this is also the case in Finland. The study also addresses whether results vary depending on a company's size or haulage sector, which relates to the general factors by Oberhofer and Fürst [15]. The research questions this paper addresses are:

(1) To what extent have Finnish road haulage companies set targets for reducing fuel consumption?

(2) How do Finnish road haulage companies monitor their fuel consumption?

(3) To what extent have Finnish road haulage companies perceived interest from their shippers towards their energy efficiency measures?

(4) What are the attitudes of Finnish road haulage companies towards environmental goals and measures?

(5) Are the attitudes towards environmental goals and the energy efficiency activity of companies connected to each other?

\section{Key Findings from Previous Research}

It has been found that stakeholder pressure sets the minimum levels for considering $\mathrm{CO}_{2}$ emissions of freight transport among companies in a certain industry or a country, although, company strategy outweighs stakeholder pressure in determining differences between companies [16]. However, despite an increasing focus on environmental issues in society, environmental factors consistently have a low level of importance in purchasing transport services [17]. Among sustainable SCM dimensions, economic sustainability is the most important criterion in carrier selection [18]. Additionally, from LSP's perspective, sustainability issues have a strong tendency towards economic and profit-related issues [19].

Generally, environmental issues and sustainability are not key priorities in companies. In a survey [20] of Finnish logistics companies $(\mathrm{N}=297)$, the most important issue to influence decision making in the medium and long term were economic factors (64\%), followed by social factors (22\%), and least important were environmental factors (14\%). Interestingly, it was found that the results were very similar between the logistics companies and the industry and trade companies.

Based on a study among large shippers in manufacturing in Sweden, Lammgård and Andersson [17] found that price was the most important factor when selecting transport services. They noted that the economic recession in 2008-2009 increased the cost focus among shippers, but when comparing survey results from 2003 and 2012, they found that environmental aspects received more attention when shippers bought transport services.

Oberhofer and Dieplinger [9] found that the position of the company in the supply chain influences its environmental behaviour. Upstream actors are the most decisive in influencing the implementation of environmental measures. Transport companies seldom face a direct end-user contact. However, an increasing number of companies in this sector are seeing that sustainable performance can contribute to added value in the long term [9].

Ellram and Golicic [21] noted that shippers were more committed to adopting sustainability in their business models compared to carriers in general. Sustainability is a co-operative effort; therefore, collaborative, long-term relationships should be fostered between the different actors in the supply chain, from buyers to suppliers and shippers to hauliers. The shippers may have more power and may view hauliers as replaceable. This cost-oriented and short-term perspective may prevent hauliers' long-term investments. Shippers should realise that even if outsourcing their haulage activity, they cannot ignore its impacts [21].

Improving environmental performance of road haulage through carbon reduction initiatives can be a demanding challenge, especially for SMEs [22]. Oberhofer and Dieplinger [9] suggest that managers of small firms may regard environmental policies as an additional burden and as a cost-factor, especially when regulations are imposed by the government. They also note that many SMEs are stuck in short-term oriented planning and goals and 
therefore are less proactive in environmental management. However, also in the context of SMEs, environmental measures can contribute to overall economic improvement [9].

Oberhofer and Fürst [15] noted that even if decision-makers' attitudes have a significant influence on companies' actual environmental performance, firm size and sector affiliation had a far greater influence. It is therefore necessary to offer external incentives and support especially for smaller companies, to improve their environmental performance. Additionally, consumer awareness should be raised to create public pressure for companies to implement environmental management in addition to policy interventions, such as legal restrictions [15].

SMEs can profit from support that motivates them to improve their environmental performance, and thus, these companies should be provided with knowledge about specific methods of improvements and financial aids [14]. SMEs could be provided with less formal environmental management systems and environmental counselling [23]. It is also noted that SMEs, which are the backbone of many national economies, must be supported to strengthen their sustainability performance to allow long-term competitiveness [9]. In addition to financial subsidies or tax abatements, successful examples of environmental measures should be communicated as well as general know-how [9].

Evangelista [13] found that support from government and management were the two highest ranked drivers for the adoption of green initiatives in 3PL companies. Additionally, green initiatives implemented by customers and support for green initiatives from entrepreneurs were considered as high importance issues by most of the case companies studied. When studying the most important barriers affecting the adoption of green initiatives, lack of a well-defined regulation framework was highly important for most companies. Another issue which was regarded as important by most of the studied Italian companies, was the lack of financial incentives. Interestingly, for some companies the customer could be seen to be both a driver and a barrier for the adoption of green initiatives [13].

An interesting question is, what are the roles and the collaboration between road freight hauliers and the shippers in shaping environmental attitudes and practices? In Finland, based on the energy efficiency agreements in freight transport, which were in place from 2008 to 2016, it was noted that the shippers (industry and trade companies) did not put pressure on the haulage companies to join the agreement [24]. However, according to Laari et al. [23], external environmental collaboration with customers would be the most effective way to improve operational and financial performance of the LSPs.

Energy efficiency agreements in freight transport in 2008-2016 were one of the tools for implementing the directive 2006/32/EC on energy end-use efficiency and energy services and later the directive 2012/27/EU on energy efficiency in Finland [25]. The goal of the agreements in freight transport was to reach a $9 \%$ reduction in energy use by 2016 compared to the average energy use in 2001-2005 [24]. Increasing the shippers' requirements to the hauliers was recognised as an essential success factor when the energy efficiency agreement in the transport sector was prepared. However, this was not realised, because shippers did not include joining the agreement as a criterion in competitive tendering. Energy efficiency of transport was clearly less stressed by shippers compared to costs and delivery reliability [24].

Lammintaus [26] presented results from a survey of trade and manufacturing companies with turnovers of over EUR one million in Finland. Environmental accountability and energy efficiency were considered more often as company turnover increased. Of the studied companies $(\mathrm{N}=270), 91.4 \%$ considered environmental accountability and energy efficiency important. However, some of the respondents from smaller companies commented that in practice, price is always the decisive factor. In many (12) open answers, environmental accountability was expressed solely as the haulier's responsibility. Some respondents brought up the need to deepen the co-operation between shippers and the haulier beyond just purchasing or tendering transactions. The hauliers' tenders should also include description of how the haulier promotes and acts in terms of accountability. 


\section{Finnish Road Haulage Sector and Hauliers}

Most of road freight in Finland is carried by dedicated road haulage companies instead of "own-account" operations by industry and trade companies. When compared to other European nations, Finland has some of the lowest rates of own-account road freight transport, with more than $80 \%$ of the tonnage and more than $90 \%$ of tonne-kilometres carried by dedicated road haulage companies [27].

In Finland, $86 \%$ of goods are transported by road, and the mileage of road haulage per transported product is greater than any other country in Europe [28]. The Finnish road freight transport sector is very fragmented. There are some large actors with large fleets and tens or hundreds of employees. There are also thousands of smaller road haulage companies. Altogether, there are about 10,000 road freight companies in Finland [28] operating with about 34,000 lorries and 7000 vans subject to permits [29]. The situation in other European countries is generally similar, where most road hauliers are small.

Figure 1 presents the development of gross domestic product (GDP), road tonnekilometres (tonne-kms) by lorries, their energy use, and $\mathrm{CO}_{2}$-eq. emissions as indexes $(2011=100)$ in Finland in 2011-2019. It is notable that the economy has grown only in the latter part of the period, whereas tonne-kms first decreased and then picked up as the economy has grown. When looking at the tonne-km statistics, it should be noted that there are yearly anomalies due to statistics being collected as a sample survey. When comparing energy use and $\mathrm{CO}_{2}$-eq. emissions with tonne-kms, a decrease can be noted after the year 2013. This is likely to be largely due to the increase in maximum gross vehicle weight in October 2013, which increased the average payloads in Finland and improved energy efficiency [30]. The low levels of $\mathrm{CO}_{2}$-eq. emissions in 2014 and 2015 relate to the high share of biodiesel used in that period. The growth in biodiesel share was due to the Finnish Act on promoting the use of biofuels for transport [31], which set the distributors of transport fuels the obligation to supply a growing share of biofuels for consumption. In 2014 and 2015, the transport fuel distributors delivered a high share of biodiesel to reach the given targets for biofuel distribution.

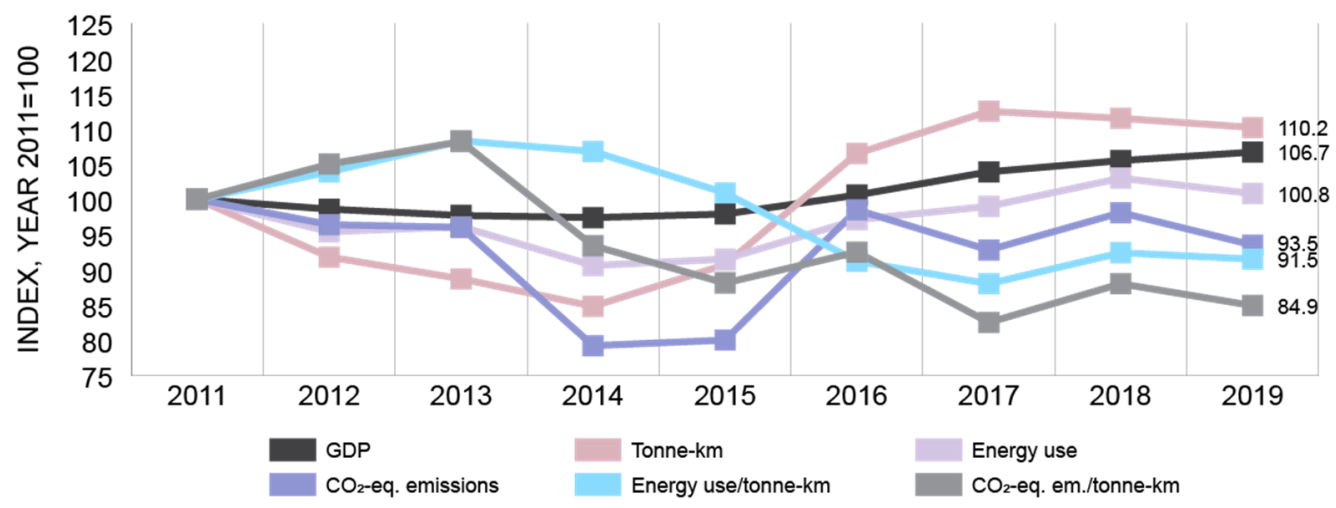

Figure 1. Development of gross domestic product (GDP) and key indicators of road haulage in Finland in 2011-2019 [32-34].

In Finland, the typical road haulage company is a family business, and $47 \%$ of the companies operate with one vehicle, $19 \%$ with two, and $10 \%$ with three vehicles [28]. When considering the classification presented by Freight Best Practice, where small operators have fleets with 1-10 vehicles, medium operators have 11-50 vehicles and large operators have 50 or more vehicles [10], almost $100 \%$ of Finnish road hauliers are small or medium operators; there are only 42 companies with 50-100 vehicles, and 9 companies with more than 100 vehicles [28]. The smaller hauliers tend to serve one specific freight market or industry according to the company's type of vehicle(s). The smaller hauliers may also be subcontractors to larger logistics service providers, which is also like the situation in other counties, e.g., in Italy [13]. In recent years, the number of registered road haulage companies has decreased in Finland, but the number of employees has increased somewhat [35]. 
This depicts a tendency towards increased company size. Return on capital invested amongst Finnish road hauliers has fluctuated around 6-7\% in 2012-2018 [35], indicating low profit margins.

The organisation Finnish Transport and Logistics SKAL represents businesses providing road haulage and logistics services in Finland. SKAL has some 4800 members, of which most are companies operating with one or two vehicles [36,37]. Some 200 of the SKAL member companies operate with more than 10 vehicles [37]. SKAL represents some $55 \%$ of the entrepreneurs engaged in the licensed haulage of goods in Finland [37].

\section{Surveys to Finnish Road Hauliers}

The 2019 survey was conducted in Finnish by SKAL members between November and December using the online survey platform Webropol. The questionnaire consisted of three parts: Part I, Automation of road transport; Part II, Energy efficiency and environment; and Part III, Background information. The total number of questions was 28. In this study, the results related to questions investigating energy efficiency and environment (part II, questions 11-14 and 18) and respondents' background information (part III, questions 24 and 28). The seven survey questions analysed in this study are as follows:

- Question 11: What is your opinion on the following statements?

1. There is a need to reduce the environmental harm and emissions from road freight transport in future;

2. Zero-level of greenhouse gas emissions from road transport by the year 2045 is a good aim;

3. Developing and implementing new technology is an acceptable way to reduce the emissions;

4. Financial policy instruments are an acceptable way to reduce the emissions;

5. Legislation-based bans and restrictions (e.g., requiring vehicles with emissions below a certain limit) are an acceptable way to reduce the emissions.

Each question was answered on a five-point Likert scale: fully agree-partly agree-neither agree nor disagree-partly disagree-fully disagree. This question relates to RQ4 and RQ5.

- Question 12: Has your company set goals for reducing fuel consumption? Options: 1. Yes, with continuing question 'what kind of targets?' and space for typing in the answer; 2. No. This question is related to RQ1 and RQ5.

- Question 13: Which of the following is the best to describe the present situation regarding fuel consumption monitoring in your company? (Choose the best suitable option in your opinion). Options:

1. Monitoring "with pen and paper" when refuelling;

2. Monitoring "with pen and paper" when refuelling, and thereafter transferring and managing the data with a computer at the office;

3. Monitoring automatically when refuelling with a telematic device or through digital services provided by the fuel station companies;

4. Continuous monitoring with a telematic device;

5. No active monitoring.

This question relates to RQ2 and RQ5.

- Question 14: In which level of detail do you monitor the fuel consumption in your company? (You can choose multiple options.) Options:

1. Total consumption at the company level;

2. Vehicle-level;

3. Customer-level;

4. Driver-level.

This question is related to RQ2. 
- Question 18: Has one or more of your shippers been interested of the energy efficiency measures of your company or about your company joining the energy efficiency agreement? Options: 1. Yes; 2. No. This question relates to RQ3.

- Question 24: What is the number of lorries and vans with which the company operates? 1. Number of lorries; 2. Number of vans. This question provides background information about the respondents' companies and was analysed relating to the different RQs.

- Question 28: What is the haulage sector of your company? (You may choose several options.) Options:

1. Distribution;

2. Groceries transport;

3. Log or paperwood transport;

4. General cargo;

5. Transport with interchangeable platform or body;

6. Soil transport;

7. Other bulk cargo;

8. Tanker/ADR transport;

9. International transport;

10. Waste and maintenance transport.

This question provides background information about the respondents' companies and was analysed in relation to the different RQs.

In the survey design, the items were chosen to allow for comparison with the previous survey, which was carried out in 2011 for a similar group of SKAL members. When preparing the 2019 survey, comments to the draft questionnaire were received from SKAL representatives, and based on these, some items were revised to increase clarity and take the respondents better into account.

The 2019 survey was directed to all members of SKAL. The invitation to answer the questionnaire and the survey link was sent by email to all SKAL members (4421) on November 6th. A reminder for the survey was sent out in a newsletter that SKAL posted to its members on November 14th. The first responses came on November 6th, and the last one was received on December 5 th.

A total of 256 respondents participated in the 2019 survey, representing a response rate of $5.8 \%$. All the responses were usable and were included in the analysis. Even though none of the survey items were obligatory, most respondents answered all or close to all questions. As a comparison, the survey in 2011 had 295 respondents and a 9.3\% response rate [12].

Based on the background information collected in the survey questionnaire, the fleet sizes of the respondents' companies in 2011 and 2019 surveys are presented in Figure 2. As expected, based on information about SKAL members in general, most of the respondents' companies were small. In the 2019 survey, there were more respondents, whose companies had two or three vehicles than in the 2011 survey. In the 2019 survey, there were fewer companies with only one vehicle. The shares of bigger companies were similar between the surveys. To compare the survey respondents to SKAL members in general, Figure 2 presents information of all licensed companies, too. The respondents in both surveys represented larger companies compared to all the SKAL members, of which almost half were one-vehicle companies. The respondents included a larger share of multi-vehicle companies compared to the whole industry.

A one-sample chi-squared test was conducted to determine how well the sample in 2019 survey $(N=252)$ generalised to the estimated population $(n=4421)$ in terms of the distribution of companies across the five size categories. Results indicated that the sample proportions of different sized companies were significantly different from the population proportions $\left(\chi^{2}(4)=91.451, p<0.001\right)$. Thus, the sample did not represent the population. 

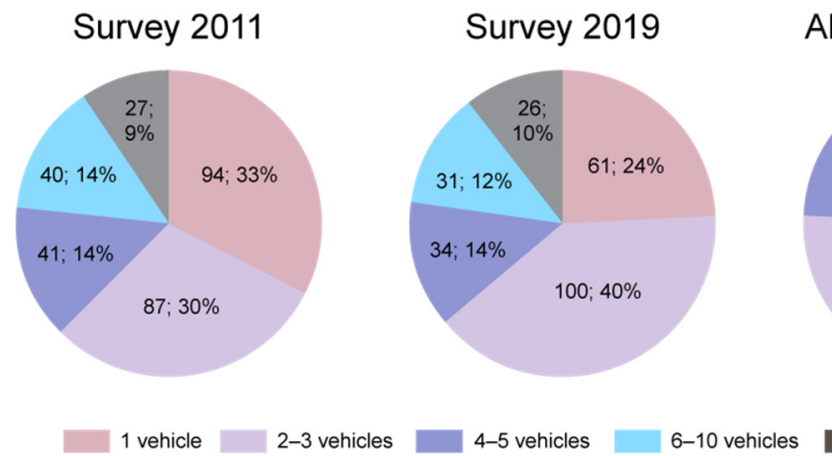

All companies 2019

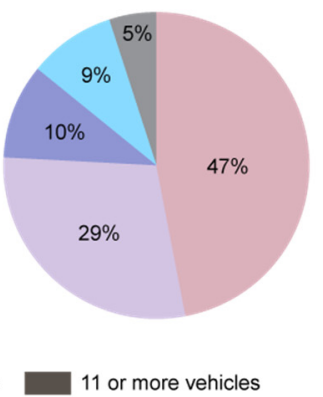

Figure 2. The number of respondents and share of respondents according to the number of vehicles in respondents' companies in the survey in $2011(\mathrm{~N}=289)$ and in $2019(\mathrm{~N}=252)$. "All companies" presents licensed road haulage companies in SKAL according to the number of vehicles [28].

Figure 3 presents the self-reported haulage sector of the respondents' companies. The companies represent all sectors with most companies in haulage of general cargo. A different classification of haulage sections was utilised compared to the 2011 survey. In 2011, the most common haulage sectors (industries served) were trade (71 respondents), construction (62), food (48), and forestry (42). Despite differences in the classifications, the represented haulage sectors among the respondents in the 2019 and 2011 surveys could be interpreted to generally be alike.

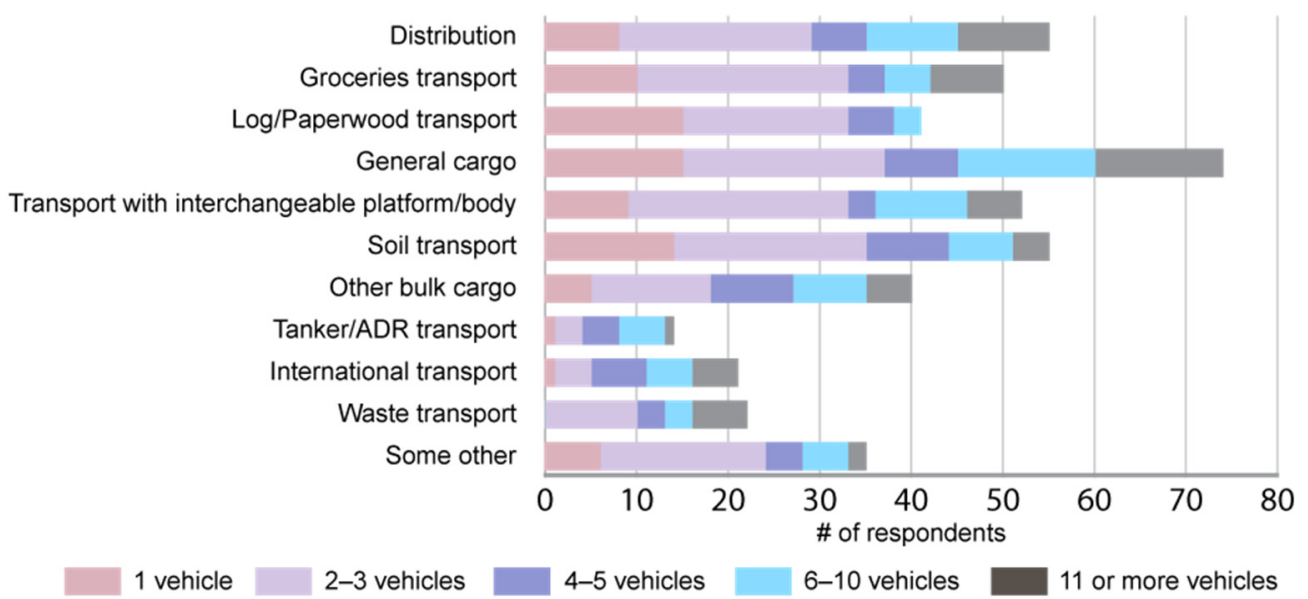

Figure 3. Road haulage sector and number of vehicles of the respondents' companies in the 2019 survey. The respondents $(\mathrm{N}=252)$ could choose several haulage sectors.

When comparing the results from 2019 and 2011 surveys, it is worth noting that even if the survey respondents represented the same organisation, many new members have joined SKAL and some of old members have become inactive. Due to the low response rates, it is unlikely that the respondents would be the same in each survey. Therefore, in testing the statistical significance of the results, the samples are considered as independent. Moreover, the statistical test of independent samples is more suitable to this kind of data and thus gives adequately reliable results of the differences between the 2019 and 2011 survey results. The statistical tests were carried out using IBM SPSS software.

\section{Results and Discussion}

This section presents the results from the 2019 survey to SKAL members and comparisons with the 2011 survey results. The results are presented and discussed in connection to previous studies and in the order of the research questions. In addition to the five RQs, the questions as to whether the results varied according to company's size and haulage sector are discussed. 
RQ1. To what extent have Finnish road haulage companies set targets for reducing fuel consumption?

The survey respondents were asked whether their company has set targets for reducing fuel consumption. In the 2019 survey, 55\% of the respondents $(\mathrm{N}=252)$ answered that they have set some targets for reducing fuel consumption. There seemed to be a minor difference between the surveys because the respective share was 56\% in $2011(\mathrm{~N}=294)$, but the difference was not statistically significant (chi-squared $p=0.234$ ). Size of the company was significantly associated with setting targets for reducing fuel consumption (chi-squared $p=0.001$ ). Companies with only one vehicle set targets for reducing fuel consumption much more rarely than bigger companies. On the other hand, companies with 4-10 vehicles have set targets more often than others. Haulage sector did not have any statistically significant effect on this issue.

During the 2010s and especially after the Paris Agreement in 2015 on limiting global warming, there was a strong increase in the sustainability discussion. As such, it could be assumed that road freight haulage companies have addressed the need for reducing emissions by setting targets for fuel consumption reduction. However, the comparison between 2011 and 2019 surveys shows that there is practically no change in setting targets.

There was clear evidence that the smallest road hauliers, operating only with one truck, are least active as only about one-third of these companies had set reduction targets, whereas the bigger companies usually had set targets. This may be due to bigger companies having more resources. Furthermore, in one-vehicle companies, the entrepreneur is usually the driver and therefore manages the consumption directly, and thus setting a specific target may be less useful. The findings that managers of small hauliers may regard environmental policies as an additional burden that increase costs as well, and the SMEs may be stuck to short-term planning [9], are relevant issues to consider. It is the smaller road haulage companies that especially need support in their sustainability actions.

RQ2. How do Finnish road haulage companies monitor their fuel consumption?

Figure 4 presents the responses to the survey question, which asked the respondents how their companies were monitoring the fuel consumption. The respondents had to choose one option, which best described the current situation in their company.

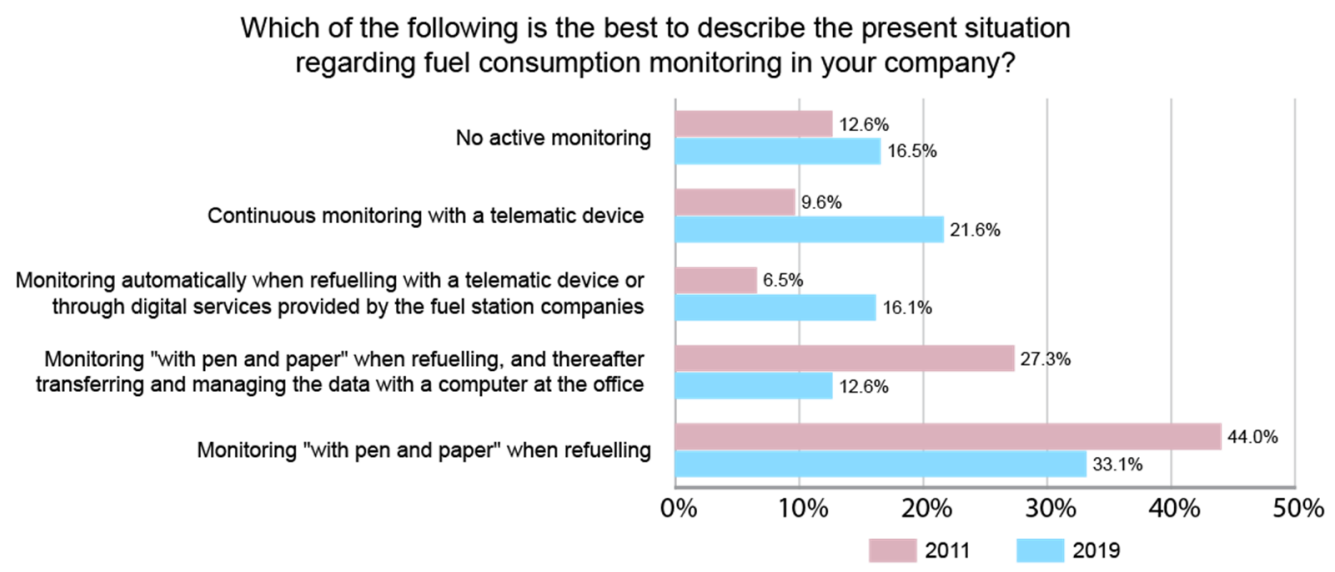

Figure 4. Fuel consumption monitoring practices in respondents' companies in 2011 (N = 293) and 2019 (N = 254) surveys.

As shown in Figure 4, statistically significant differences between the 2019 and 2011 surveys were found (chi-squared $p<0.001$ ). Monitoring with telematic devices (both when refuelling and continuously) has become much more popular over the years. However, the "pen and paper" method was still popular in 2019 and only about 38\% of the companies used telematic devices for fuel consumption monitoring. There was also a notable share of respondents (17\%) in 2019, who did not have active monitoring at all in their company. There were some differences in the distribution of answers depending on the size of the company and company's haulage sector. Larger companies (chi-squared $p=0.002$ ) and 
companies operating in groceries transport (chi-squared $p=0.005$ ) use more advanced monitoring technology than others. On the other hand, companies operating in transport with interchangeable platform/body sector used less advanced technology for monitoring than others.

Based on the survey results, the Finnish road haulage companies increased the use of telematic devices in fuel consumption monitoring during the 2010s. This has also been noted in the Finnish context, where wireless monitoring systems have replaced manual practices [24]. However, the development in road hauliers' practices is slow; the most used monitoring method is still "pen and paper" instead of more automated and ICTbased solutions. Slow adoption of more advanced monitoring solutions, such as automatic monitoring at the pump or on-board monitoring, could also be seen in the beginning of 2010s in Germany among large hauliers [11] and among small British hauliers [10], and this study confirms that this trend continues. Regarding the different haulage sectors, groceries transport companies were more active. This may be due to the nature of this sector, because groceries shippers are usually more demanding customers compared to the interchangeable platform/body sector, in which the typical transports in Finland include containers, soil materials, scrap metal and other recycled materials.

Figure 5 presents the results to the survey question, which asked the respondents about the level of monitoring fuel consumption in their company. Respondents were able to choose multiple options.

\section{In which level of detail do you monitor the fuel} consumption in your company?

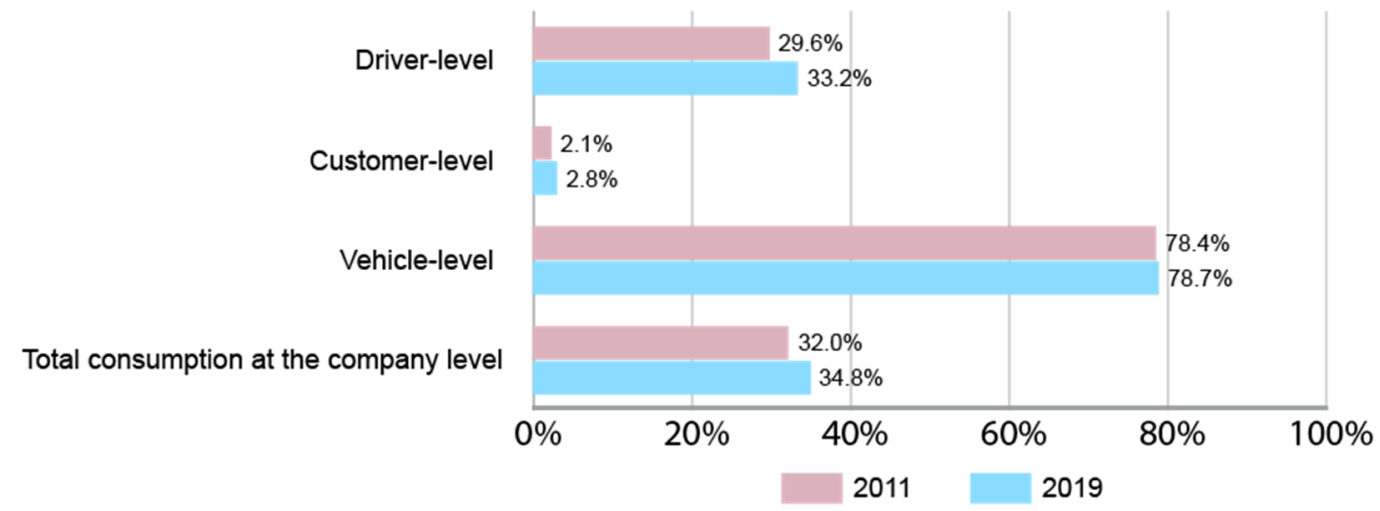

Figure 5. The level of monitoring fuel consumption in respondents' companies in the $2011(\mathrm{~N}=291)$ and $2019(\mathrm{~N}=253)$ surveys. Respondents were able to choose multiple options.

As can be seen from Figure 5, most of the respondents' companies were monitoring the fuel consumption at the vehicle-level. About one-third of the companies had driver-level or company-level monitoring in place, but only a few companies were monitoring the consumption at the customer-level in 2019. The differences between the results of the 2011 and 2019 surveys are minor and not statistically significant (chi-squared $p_{\text {driver }}=0.360$, $p_{\text {customer }}=0.591, p_{\text {vehicle }}=0.931, p_{\text {total }}=0.486$ ). Again, there were some small differences in the responses depending on company size and haulage sector in the 2019 survey. The larger companies (six or more vehicles) monitored the total fuel consumption at the company level more often than others, however companies with 4-5 vehicles were doing so more rarely than others (chi-squared $p=0.031$ ). Size of the company did not have any statistically significant effect on the other monitoring levels. It was also found that companies operating in the soil transport sector monitored the total consumption more often at the company level (chi-squared $p=0.010$ ) and more rarely at the vehicle level than others (chi-squared $p=0.032$ ). At the driver level, the only statistically significant effect was that companies in the other bulk cargo sector were monitoring the consumption at the driver level more often than others (chi-squared $p=0.014$ ). 
Related to the level in which the hauliers monitored their fuel consumption, the situation had not changed between 2011 and 2019, even though the increase in use of more advanced monitoring systems would allow monitoring to be in place on different levels. Bigger hauliers, perhaps due to their larger resources and connections to their customers, were found to be somewhat more active in deploying monitoring at the company level, but not at other levels. The customers of bigger hauliers may also more often be larger companies which have more ambitious targets related to sustainability, and as such require their LSPs to provide information about their emissions.

RQ3. To what extent have Finnish road haulage companies perceived interest from their shippers towards their energy efficiency measures?

Respondents were asked whether one or more of their company's shippers were interested in energy efficiency measures or about whether the company has joined the energy efficiency agreement. Both in 2019 and 2011 surveys, fewer than $20 \%$ of the respondents (in 2019 the percentage was $19.7 \%, \mathrm{~N}=254$; and in 2011 it was $18.7 \%, \mathrm{~N}=289$ ) stated that the shippers have been interested in these issues. No significant change occurred in the distribution of answers between the 2019 and 2011 survey responses (chi-squared $p=0.768$.

Liimatainen et al. [12] found that respondents, whose companies represented certain haulage sectors, reported more interest from their shippers than others in the 2011 survey. In the 2011 survey, especially the hauliers who the served the energy sector, technology as well as chemical industries reported more interest from their shippers. In the 2019 survey, the only statistically significant differences in the shippers' interest towards energy efficiency were found in log and paperwood and general cargo haulage. The shippers of $\log$ and paperwood haulage companies have expressed less interest in energy efficiency compared to other sectors. On the other hand, the general cargo shippers have expressed more interest in their haulier's energy efficiency. It is possible that the tanker/ADR and waste and maintenance transport shippers may express more interest towards their hauliers, but due to the low number of respondents representing these groups, this could not be validated. Table 1 presents the shippers' expressed interest in energy efficiency according to the responses from companies in the different haulage sectors.

Table 1. Share of respondents in different road haulage sectors perceiving interest from their shippers about company's energy efficiency measures or about joining the energy efficiency agreement and chi-squared tests results between the respondents whose companies operate in a certain sector compared to the those which do not in the 2019 survey. The prerequisites for using chi-squared test were not fulfilled with three of subgroups, because they had expected counts of less than 5 in one or more cells. These are marked as ' - ' in the table.

\begin{tabular}{cccc}
\hline Haulage Sector & N & $\begin{array}{c}\text { Share of Respondents Who Have } \\
\text { Perceived Interest from Shippers }\end{array}$ & Chi-Squared \\
\hline Distribution & 55 & $20.0 \%$ & 0.947 \\
Groceries Transport & 50 & $22.0 \%$ & 0.646 \\
Log or Paperwood Transport & 42 & $4.8 \%$ & 0.008 \\
General Cargo & 74 & $28.4 \%$ & 0.025 \\
Transport with Interchangeable Platform or Body & 52 & $26.9 \%$ & 0.141 \\
Soil Transport & 57 & $19.3 \%$ & 0.934 \\
Other Bulk Cargo & 40 & $22.5 \%$ & 0.626 \\
Tanker/ADR Transport & 14 & $35.7 \%$ & - \\
International transport & 21 & $23.8 \%$ & - \\
Waste and Maintenance Transport & 22 & $40.9 \%$ & $19.7 \%$ \\
Total & 254 & & - \\
\hline
\end{tabular}

Based on the 2019 survey results, the size of the company (number of vehicles) did not have a statistically significant effect on the interest of the shippers (chi-squared $p=0.057$ ). In addition, a t-test was performed to confirm that there were no statistically significant differences $(t(252)=1.265, p=0.207$, two-tailed $)$. 
Only about one fifth of survey respondents in 2019 survey had perceived interest from their shippers towards the energy efficiency measures of their company. The situation has not changed when comparing the results with the 2011 survey. If shippers are currently more environmentally aware, it is not reflected by their hauliers in Finland. Is this due to the shippers and hauliers only focusing on price in their bids and negotiations and expecting that the environmental and energy efficiency issues are taken care of and addressed by the haulier even if these are not discussed? It has been noted that transport providers should know shippers' preferences when considering the marketing of environmentally preferable transport services [17]. There is likely a mismatch between the knowledge of both the shippers and hauliers about the preferences and possibilities for haulage operations which cause less environmental damage. Regarding different haulage sectors, the 2019 survey highlighted the general cargo haulage sector to have witnessed more interest from their shippers, whereas respondents from the log and paperwood haulage sector had perceived less interest. The differences in the perceived interest from shippers may also relate to more connections overall to the shippers by the companies in general cargo haulage.

RQ4. What are the attitudes of Finnish road haulage companies towards environmental goals and measures?

Figure 6 presents the responses to five statements related to companies' attitudes towards environmental goals and measures in the 2019 survey. There is no comparison presented because similar statements were not included in the 2011 survey.

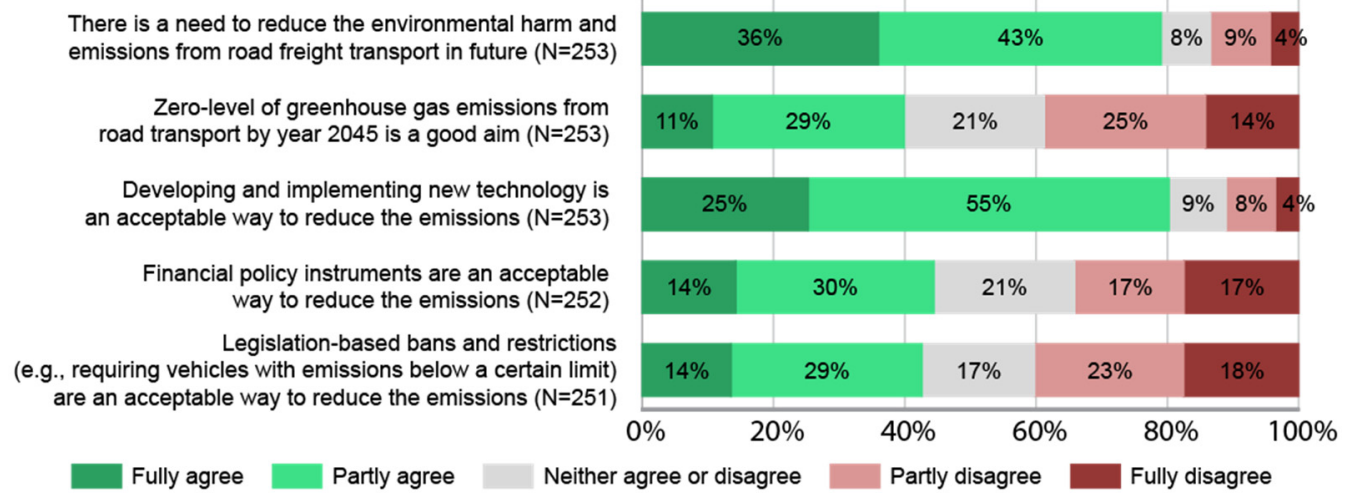

Figure 6. Finnish road hauliers' responses to five statements on the environmental goals and measures in the 2019 survey.

As shown in Figure 6, 36\% of the respondents fully agreed and $43 \%$ somewhat agreed that environmental damage and emissions from road freight transport must be strived to be reduced in future. However, only $11 \%$ fully agreed and $29 \%$ somewhat agreed that reaching zero greenhouse gas emissions from road transport by 2045 is a good target. In Finland, this target by 2045 has been studied by a working group (see [38]) and discussed publicly and in the media.

Related to emission reduction measures, the development of new technology was considered as the most acceptable method of the listed options, because almost $80 \%$ of the respondents at least somewhat agreed with this statement. Financial policy instruments and legislation-based bans and restrictions were considered as significantly less acceptable methods, although a larger share of respondents still agreed with the statement that these are acceptable methods to reduce emissions. Based on cross tabulations (chi-squared test) and comparing means (ANOVA), the company size measured with the number of vehicles in use did not have a statistically significant influence on the answer distribution in any of the presented statements. Related to companies' haulage sector, the only statistically significant results were that companies operating in groceries transport were more positive towards the statements three (i.e., they have a higher acceptancy of developing and implementing new technology, chi-squared $p=0.001$ ) and five (legislation-based bans and restrictions, chi-squared $p=0.017$ ). 
Most respondents (79\%) in the 2019 survey agreed with the statement that there is a need to reduce the environmental harm and emissions from road freight in future. However, it should be noted that even with this statement, over one-fifth of the respondents either disagreed with the statement or chose the neutral response. Related to the different ways to reduce emissions, developing and implementing new technology was clearly the most supported option, whereas financial policy instruments and legislation-based bans and restrictions divided the respondents quite evenly to either agree or disagree. Oberhofer and Fürst [15] stated that SME hauliers were unlikely to invest in environmental measures beyond "compliance" unless they came under economic or legal pressure. New legislation, which polarised opinions in the responses, may be needed for reaching substantial emission reductions. Even if there were some differences between the respondents' views on some statements according to their haulage sector, e.g., between the companies operating in groceries haulage and other sectors, the number of respondents representing this specific sector was low $(\mathrm{N}=50)$. Therefore, no significant conclusions could be drawn on the issue that some haulage sectors would have a more positive attitude towards environmental goals and measures.

RQ5. Are the attitudes towards environmental goals and the energy efficiency activity of companies connected to each other?

Finally, an analysis was performed as to whether there is a connection between company's active practices in energy efficiency and the attitudes towards the statements one and two presented in Figure 6. An "active" company was defined as a company which had set a target for reducing fuel consumption and was monitoring the consumption actively (at least "with pen and paper" method). With this definition there were 128 active and 123 non-active companies in the 2019 survey. No statistically significant differences in responses to the two statements were found between the active and non-active companies. Based on cross-tabulations (chi-squared) and comparison of means (t-tests), haulier's activities in energy efficiency do not relate to the general attitudes towards emission reductions. This is in contrast with previous research [15] that noticed a significant influence of attitude towards sustainability on a company's actual environmental behaviour among Austrian hauliers. However, the study concluded that it seems that poor environmental performance of the smaller companies follows from a lack of opportunities rather than from a poor attitude.

\section{Closing Remarks and Research Limitations}

The results from the 2019 survey showed that respondents from Finnish road haulage companies are environmentally aware, because most of them shared the view that environmental damage and emissions from road freight transport must be reduced in the future. However, many of respondents' companies tended to still be inactive in their environmental practices. When comparing the results between the 2019 and 2011 surveys, there was practically no change in setting targets for reducing fuel consumption, nor in shippers' perceived interest towards energy efficiency, but a shift could be seen in fuel consumption monitoring. When analysing these results in the context of the development of GDP, road tonne-kms, energy use and $\mathrm{CO}_{2}$-eq. emissions in Finland in 2011-2019 (presented in Figure 1), the positive developments in energy efficiency and $\mathrm{CO}_{2}$-eq. emissions per tonne-kms, are explained by issues other than those found in the surveys, namely, the increase in maximum gross vehicle weight and rising share of biodiesel use.

The survey respondents in 2019 did not represent the population of SKAL member companies, because the respondents were more often larger hauliers than one-vehicle companies which are typical in Finland. This affects the generalisability of the results, because the larger companies showed somewhat more active environmental practices, for example, in setting targets for fuel consumption reduction and using more advanced technology in consumption monitoring. There were fewer one-vehicle companies presented among the survey respondents; therefore, the results for the whole Finnish road haulage sector may present less developed environmental practices. Additionally, the number of survey respondents presented a small portion of Finnish road haulage companies in both 
2019 and 2011 surveys. Consequently, and given the low response rate, the respondents may be more environmentally aware and development-oriented than average hauliers. Laari et al. [23] have suggested that the samples tend to be biased towards environmentally proactive companies. Therefore, future research should seek to collect more representative samples. This type of research survey may also be affected by the social desirability bias [14]. The results may somewhat depict the stated preference and differ from the actual situation. However, responding anonymously tackles much of the possible social desirability bias effect and as well as the uncertainty related to stated vs. revealed preferences.

\section{Conclusions}

A clear majority $(79 \%)$ of the survey respondents agreed with the statement that environmental damage and emissions from road freight transport must be reduced into the future. Even though the need for reducing emissions is recognised, the hauliers have not become more active in many of their practices related to energy efficiency, e.g., setting targets for reducing fuel consumption and monitoring the consumption. We can come to the same conclusion as Liimatainen et al. [12] that there seems to be opportunities for gaining competitive advantages for a haulier that excels in energy efficiency monitoring, reporting and improvements, because the practices are often still undeveloped in the market. However, it is unclear how much this would really be a competitive advantage, because the supply chain actors are generally cost- and profit-oriented. The competitive advantage depends on the environmental attitudes and practices of the shippers and large LSPs who purchase hauliers' services. Therefore, gaining a real sustainable competitive advantage requires active measures and cooperation of all parties in the SC. As Evangelista [13] has noted, the customer may be both a driver and a barrier for adopting green initiatives.

The results show that respondents' companies have not widely implemented fuel consumption monitoring practices even though the need to reduce emissions is widely recognised. The hauliers should be supported and encouraged to pursue more environmentally aware practices, but environmental accountability should not solely be the haulier's responsibility. In the 2019 survey, the most hauliers stated that they had no perceived interest from their shippers towards energy efficiency. The pressure for more sustainable operation and increased energy efficiency should come from the clients (LSPs, companies in industry and trade, and their end customers, i.e., consumers) through the supply chain and be shifted to the hauliers operating the goods transport. From the small hauliers' point of view, there could be a larger logistics operator as an intermediator, which is in contact and has the contract with the client, and therefore the SME haulier may not have a direct relationship with the customers and their policies and needs related to sustainability. The sustainability requirements should therefore be passed on in the transport chain from the logistics operator to the very end. As Laari et al. [23] have noted, external environmental collaboration with customers would be the most effective way to improve operational and financial performance of LSPs, and this should be transferred to SME hauliers. The challenge is that most companies are strongly profit-oriented, and if sustainability and energy efficiency issues are not seen to produce financial benefits, they may be ignored. As Laari et al. [23] found, environmental issues and sustainability are not key priorities in companies. Instead, the most important issues to influence decision making in the medium and long term are the economic factors. Therefore, the economic instruments, such as incentives for more sustainable operation, e.g., purchasing a low-emission goods vehicle, should be linked to economic performance and improving environmental sustainability.

The attitudes of representatives of road freight companies should be further studied because there is only a small amount of previous research on the issue. In this study, we did not find a connection between the attitudes and the actual activity in companies' environmental practices, but previous studies suggest that they are related. The attitudes towards different measures are also important when considering the different policies for more sustainable freight transport. Within this setting, we managed to have respondents from only a small portion of companies. The results of this study do not present the whole Finnish 
road haulage sector, and there was some overrepresentation of larger companies among the survey respondents. Therefore, the results must be generalised with caution. Further studies should seek for a larger number of responses and more representative results.

Author Contributions: Conceptualisation, M.P., T.L., E.K. and H.L.; methodology, T.L., H.L. and M.P.; software, T.L.; validation, T.L., M.P. and H.L.; formal analysis, T.L.; investigation, T.L. and M.P.; resources, H.L.; data curation, T.L.; writing—original draft preparation, M.P. and T.L.; writing-review and editing, M.P., T.L., E.K. and H.L.; visualisation, M.P.; supervision, H.L.; project administration, T.L. and H.L.; funding acquisition, H.L. All authors have read and agreed to the published version of the manuscript.

Funding: This research was funded by the KONE FOUNDATION, grant number b4b919. The APC was funded by Tampere University.

Institutional Review Board Statement: Not applicable.

Informed Consent Statement: Informed consent was obtained from all subjects involved in the study.

Data Availability Statement: The data presented in this study are available on request from the corresponding author. The survey data are not publicly available due to ongoing research and publication processes but will be later made accessible via the Finnish Social Science Data Archive. Additionally, publicly available datasets were analysed in this study. These data can be found using the links provided in the references.

Acknowledgments: We would like to acknowledge Finnish Logistics and Transport SKAL for the assistance in conducting the survey. We would also like to thank all the respondents of the survey. We thank our colleagues for their help: Riku Viri with finishing the figures, Hanne Tiikkaja with statistical tests, and Steve O'Hern with proofreading.

Conflicts of Interest: The authors declare no conflict of interest. The funders had no role in the design of the study; in the collection, analyses, or interpretation of data; in the writing of the manuscript, or in the decision to publish the results.

\section{References}

1. Wu, H.; Dunn, S.C. Environmentally responsible logistics systems. Int. J. Phys. Distrib. Logist. Manag. 1995, 25, 20-38. [CrossRef]

2. ITF. ITF Transport. Outlook 2017; OECD Publishing: Paris, France, 2017.

3. Edenhofer, O.; Pichs-Madruga, R.; Sokona, Y.; Farahani, E.; Kadner, S.; Seyboth, K.; Adler, A.; Baum, I.; Brunner, S.; Eickemeier, P.; et al. (Eds.) Climate Change 2014: Mitigation of Climate Change. Contribution of Working Group III to the Fifth Assessment Report of the Intergovernmental Panel on Climate Change; Cambridge University Press: Cambridge, UK; New York, NY, USA, 2014.

4. Mulholland, E.; Teter, J.; Cazzola, P.; McDonald, Z.; Gallachóir, B.P.Ó. The long haul towards decarbonising road freight-A global assessment to 2050. Appl. Energy 2018, 216, 678-693. [CrossRef]

5. A European Green Deal. Available online: https://ec.europa.eu/info/strategy/priorities-2019-2024/european-green-deal_en\# actions (accessed on 17 April 2020).

6. Herold, D.M.; Lee, K.-H. Carbon management in the logistics and transportation sector: An overview and new research directions. Carbon Manag. 2017, 8, 79-97. [CrossRef]

7. Walnum, H.J.; Aall, C. Transportation: Challenges to Curbing Greenhouse Gas Emissions from Road Freight Traffic. In Rethinking Climate and Energy Policies; Springer Science and Business Media LLC: Berlin/Heidelberg, Germany, 2016; pp. $243-266$.

8. Nilsson, F.R.; Sternberg, H.; Klaas-Wissing, T. Who controls transport emissions and who cares? Investigating the monitoring of environmental sustainability from a logistics service provider's perspective. Int. J. Logist. Manag. 2017, 28, 798-820. [CrossRef]

9. Oberhofer, P.; Dieplinger, M. Sustainability in the Transport and Logistics Sector: Lacking Environmental Measures. Bus. Strat. Environ. 2014, 23, 236-253. [CrossRef]

10. AECOM. Integrated Research Study: Small Haulier. Freight Best Practice Programme; Department for Transport: London, UK, 2010.

11. Tacken, J.; Sanchez Rodrigues, V.; Mason, R. Decarbonisation initiatives applied within the German logistics sector. In Proceedings of the 16th International Symposium on Logistics (ISL 2011), Berlin, Germany, 10-13 July 2011.

12. Liimatainen, H.; Stenholm, P.; Tapio, P.; McKinnon, A. Energy efficiency practices among road freight hauliers. Energy Policy 2012, 50, 833-842. [CrossRef]

13. Evangelista, P. Environmental sustainability practices in the transport and logistics service industry: An exploratory case study investigation. Res. Transp. Bus. Manag. 2014, 12, 63-72. [CrossRef]

14. Oberhofer, P.; Fürst, E. Environmental management in the transport sector: Findings of a quantitative survey. EuroMed J. Bus. 2012, 7, 268-279. [CrossRef] 
15. Oberhofer, P.; Fürst, E. Sustainable Development in the Transport Sector: Influencing Environmental Behaviour and Performance. Bus. Strateg. Environ. 2013, 22, 374-389. [CrossRef]

16. Pålsson, H.; Kovács, G. Reducing transportation emissions-a reaction to stakeholder pressure or a strategy to increase competitive advantage. Int. J. Phys. Distr. Log. 2014, 44, 283-304. [CrossRef]

17. Lammgård, C.; Andersson, D. Environmental considerations and trade-offs in purchasing of transportation services. Res. Transp. Bus. Manag. 2014, 10, 45-52. [CrossRef]

18. Davis-Sramek, B.; Thomas, R.W.; Fugate, B.S. Integrating Behavioral Decision Theory and Sustainable Supply Chain Management: Prioritizing Economic, Environmental, and Social Dimensions in Carrier Selection. J. Bus. Logist. 2018, 39, 87-100. [CrossRef]

19. Abbasi, M.; Nilsson, F. Developing environmentally sustainable logistics: Exploring themes and challenges from a logistics service providers' perspective. Transp. Res. Part D 2016, 46, 273-283. [CrossRef]

20. Solakivi, T.; Ojala, L.; Laari, S.; Lorentz, H.; Kiiski, T.; Töyli, J.; Malmsten, J.; Bask, A.; Rintala, O.; Paimander, A.; et al. Logistiikkaselvitys 2018; Turun Kauppakorkeakoulu: Turku, Finland, 2018.

21. Ellram, L.M.; Golicic, S.L. The role of legitimacy in pursuing environmentally responsible transportation practices. J. Clean. Prod. 2016, 139, 597-611. [CrossRef]

22. Groschopf, W.; Fuerst, E.; Kummer, S.; Herold, D. Identifying Carbon Reduction Potentials in Road Transportation: Creating a Carbon-Tracking Tool for Small and Medium Enterprises (SMEs). Environ. Clim. Technol. 2019, 23, 98-110. [CrossRef]

23. Laari, S.; Solakivi, T.; Töyli, J.; Ojala, L. Performance outcomes of environmental collaboration. Balt. J. Manag. 2016, 11, 430-451. [CrossRef]

24. Peltola, V. Tavarankuljetusten Ja Logistiikan Energiatehokkuussopimus. Loppuraportti 2008; Finnish Transport Safety Agency: Helsinki, Finland, 2017.

25. Energy Efficiency Agreements 2008. Available online: https:/ / energyefficiencyagreements2008-2016.fi/etusivu (accessed on 6 May 2021).

26. Lammintaus, H. Vastuullisuuden Nykytila Tavaraliikenteen Tiekuljetushankinnoissa; Finnish Transport and Communications Agency Traficom: Helsinki, Finland, 2019.

27. Stojanović, Đurđica Road freight transport outsourcing trend in Europe-what do we really know about it? Transp. Res. Procedia 2017, 25, 772-793. [CrossRef]

28. Maanteiden Tavaraliikenne Suomessa (Road Freight Transport in Finland). Available online: https://www.skal.fi/sites/default/ files/sisaltosivujen_tiedostot/skal_toimialakatsaus_2019_web.pdf (accessed on 4 May 2021). (In Finnish).

29. Cars by Purpose of Use and by Possessor. Available online: http://pxnet2.stat.fi/PXWeb/pxweb/en/StatFin/StatFin_lii_ _mkan/statfin_mkan_pxt_11td.px/(accessed on 7 March 2020).

30. Liimatainen, H.; Pöllänen, M.; Nykänen, L. Impacts of increasing maximum truck weight—case Finland. Eur. Transp. Res. Rev. 2020, 12, 1-12. [CrossRef]

31. Laki Biopolttoaineiden Käytön Edistämisestä Liikenteessä (Act on Promoting the Use of Biofuels for Transport). Available online: https: / / www.finlex.fi/fi/laki/ajantasa/2007/20070446 (accessed on 30 April 2021). (In Finnish).

32. Gross Domestic Product and National Income, Supply and Demand, Annually. Available online: http:/ / pxnet2.stat.fi/PXWeb/ pxweb/en/StatFin/StatFin_kan_vtp/statfin_vtp_pxt_11sf.px/ (accessed on 3 September 2020).

33. Volume of Goods, Vehicle Mileage and Transport Performance of Domestic Road Transport. Available online: http:/ / pxnet2.stat. $\mathrm{fi} /$ PXWeb/pxweb/en/StatFin/StatFin_lii_kttav/statfin_kttav_pxt_11il.px/ (accessed on 3 September 2020).

34. Finnish Road Emissions Calculation System. Available online: http:/ /lipasto.vtt.fi/liisa/aikasarja.htm (accessed on 3 September 2020).

35. Structural Business and Financial Statement Statistics. Available online: http://pxnet2.stat.fi/PXWeb/pxweb/en/StatFin/ StatFin_yri_yrti_oik/statfin_yrti_pxt_11qb.px/table/tableViewLayout1/ (accessed on 3 September 2020).

36. SKAL in Brief. Available online: https://www.skal.fi/en/finnish-transport-and-logistics-skal/skal/skal-brief (accessed on 8 March 2020).

37. SKAL Membership. Available online: https://www.skal.fi/en/finnish-transport-and-logistics-skal/skal/membership (accessed on 8 March 2020).

38. Särkijärvi, J.; Jääskeläinen, S.; Lohko-Soner, K. (Eds.) Action Programme for Carbon-Free Transport. Final Report by the Transport. Climate Policy Working Group; Ministry of Transport and Communications: Helsinki, Finland, 2018. 